\title{
EDITORIAL MATTERS
}

We are delighted to announce that Wlodek Rabinowicz of the University of Lund will be joining John Broome and Philippe Mongin as a third editor of the journal. We are equally pleased to announce that Christopher Morris of Bowling Green State University has become our book-review editor. Christopher replaces Margaret Schabas, to whom we should like to express our thanks for the excellent service she has done the journal for many years.

We should also like to thank our editorial assistant Ann Broome, and all the following people for generously giving their time as referees in the year up to July 1997.

Christian Arnsperger

Pierluigi Barrotta

Chris Bertram

V. Bhaskar

Jack Birner

Giacomo Bonanno

Sam Bowles

Geoffrey Brennan

Vivienne Brown

Bruce Caldwell

David Collard

Richard Cookson

Garrett Cullity

John B. Davis

Graham Dawson

Marco Del Seta

Len Doyal

Marc Fleurbaey

Duncan Foley

Ray Frey

Keith Graham

Nicolas Gravel

Francesco Guala

Alan Hájek

Alan Hamlin

Daniel Hammond

Daniel Hausman

Heinz Hollander

Kevin Hoover

Bill Jordan

\author{
Steven Kuhn \\ Maurice Lagueux \\ Jean-Francois Laslier \\ Andy Levine \\ George Loewenstein \\ Colin MacLeod \\ Dennis McKerlie \\ Steve Medema \\ Klaus Nehring \\ Mark Nelson \\ Remco Oostendorp \\ Andreas Papandreou \\ Derek Parfit \\ In-Uck Park \\ Philip Pettit \\ Louis Putterman \\ Eric Renault \\ Peter Schaber \\ Brian Skyrms \\ David Squires \\ Robert Stalnaker \\ Robert Stern \\ Robert Sugden \\ Kotaro Suzumura \\ Robert Urquhart \\ Amis Vilks \\ Peter Wakker \\ Bernard Walliser \\ Darren Wilkinson \\ Marcel Wissenburg
}




\section{CONTRIBUTORS}

David A. Bessler is Professor of Agricultural Economics at Texas A\&M University. He holds a Ph.D. in agricultural economics from the University of California at Davis.

Ken Binmore is a mathematician-turned-economicst who has written widely on the foundations of game theory and evolutionary processes. The second volume of his Game Theory and the Social Contract will be published by MIT Press in 1997. He currently holds a Leverhulme Research Chair at University College London, where he directs the ESRC Centre for Economic Learning and Social Evolution.

Charles Blackorby is Professor of Economics at the University of British Columbia and a member of GREQAM. He has published articles on welfare economics, duality and aggregation.

Walter Bossert is Professor of Economics at the University of Nottingham. He has published articles on social choice theory and rational choice.

Vivienne Brown is Senior Lecturer in Economics at The Open University, UK. Her research interests include interdisciplinary history of economic thought, language and economics as discourse. She is the author of Adam Smith's Discourse: Canonicity, Commerce and Conscience (1994) and is now working on a book provisionally entitled John Locke, Language and Liberalism.

David Dearmont is Administrator of the Research Division, Nebraska Department of Revenue. He holds a Ph.D. in agricultural economics from Texas A\&M University.

David Donaldson is Professor of Economics at the University of British Columbia. He has published articles on social choice theory and welfare economics.

Ben Fine is Professor of Economics and Director of the Centre for Economic Policy for Southern Africa, School of Oriental and African Studies, University of London. Recent books include Consumption in the Age of Affluence: the World of Food, with Michael Heasman and Judith Wright, and South Africa's Political Economy: From Minerals-Energy Complex to Industrialisation, with Zavareh Rustomjee. 
Philippe Fontaine is Professor of Economics at the École normale supérieure de Cachan. He is co-editor of Historical Perspectives on Macroeconomics (Routledge, forthcoming) and his current research interests are in the relationships between economics and psychology.

Shaun P. Hargreaves Heap teaches economics at the University of East Anglia. His recent research has been on rationality in economics and on the New Keynesian macroeconomics.

Ken Kress is Professor of Law and University Faculty Scholar at the University of Iowa. He has been Visiting Professor of Law at the University of Virginia and at the University of California (Hastings). He has published in the areas of jurisprudence, legal reasoning, legal indeterminacy, cuherence, tort law and tort theory. He is currently at work on a book on the normative value of coherence, especially in law.

Luc Lauwers received his Ph.D. in Economics from the KULeuven with a dissertation entitled 'Social choice with infinite populations'. He teaches in the Faculty of Economics and Applied Economics of the KULeuven.

Luc Van Liedekerke is a researcher at the UFSIA University, Antwerp. His main interests are social choice theory and utilitarian ethics.

Stephen Parsons is Principal Lecturer in Economics at De Montfort University, Milton Keynes, where he lectures in political theory and the philosophy of the social sciences. He is currently working on the philosophical underpinnings of rational ethical theory.

Salim Rashid is Professor of Economics at the University of Illinois at UrbanaChampaign. He received his Ph.D. from Yale in Mathematical Economics. His main interests are in the history of economics, economic development and the relationship between christianity and economics.

Kristin Shrader-Frechette, President of the Risk Analysis and Policy Association, is Distinguished Research Professor in the Philosophy Department and the Environmental Science Program at the University of South Florida. With degrees in mathematics, physics and philosophy of science, she has held post-docs in both economics and hydrogeology. Her 14 authored books include Science Policy, Ethics, and Economic Methodology (1983), Risk and Rationality (1991), and Risk and the Case Against Geological Disposal of Nuclear Waste (1993).

Hamish Stewart is Assistant Professor in the Faculty of Law, University of Toronto. His publications include papers on the law of contract, the law of evidence and economic methodology.

Peter Vallentyne is Associate Professor and Chair of Philosophy at the Virginia Commonwealth University. He edited Contractarianism and Rational Choice: Essays 


\section{CONTRIBUTORS}

on the Work of David Gauthier, and has written on a variety of issues in consequentialist moral theory. He is currently developing a version of leftlibertarianism (combining self-ownership with egalitarianism).

Amos Witztum is a senior lecturer in Economics at the London Guildhall University. He also taught at the London School of Economics and the Hebrew University of Jerusalem. His main interest is the problem of ethics-economics relationship past as well as present. 


\title{
ECONOMICS AND PHILOSOPHY
}

\author{
Volume 13
}

1997

\section{CAMBRIDGE}

UNIVERSITY PRESS 
Contents of Volume 13

Essays

K. R. SAWYER, CLIVE BEED Underdetermination in AND H. SANKEY

The Duhem-Quine Thesis 1

ROGER E. BACKHOUSE An 'Inexact' Philosophy of Economics

25

PIERPAOLO BATTIGALLI The Logic of Belief Persistence 39

AND GIACOMO BONANNO

CHRISTIAN ARNSPERGER Reforming Equality of Resources

61

PIERS RAWLING

Expected Utility, Ordering, and

Context Freedom 79

GRAHAM DAWSON

Exit, Voice and Values in

Economic Institutions 87

DAVID DEARMONT AND A Bayesian Treatment of Duhem's Thesis:

DAVID A. BESSLER

The Case of the 'Farm Problem' in

Agricultural Economics 149

LUC VAN LIEDERKERKE

AND LUC LAUWERS

Sacrificing the Patrol: Utilitarianism, Future Generations and Infinity 159

STEPHEN D. PARSONS

CHARLES BLACKORBY, WALTER BOSSERT AND DAVID DONALDSON

HAMISH STEWART

AMOS WITZTUM

Mises, the A Priori, and the Foundations of Economics: A Qualified Defence 175

Critical-Level Utilitarianism and the Population-Ethics Dilemma 197

The Law of Damages and the Prisoners' Dilemma: A Comment on 'Pure and Utilitarian Prisoners' Dilemmas 231

Distributive Considerations in Smith's Conception of Economic Justice 241

PHILIPPE FONTAINE Identification and Economic Behavior Sympathy and Empathy in Historical Perspective $\mathbf{2 6 1}$

VIVIENNE BROWN

'Mere Inventions of the Imagination: $A$ Survey of Recent Literature on Adam Smith 281 
Comments

ELIZABETH ANDERSON

JOHN R. ROWAN

Reviews

ARIEL RUBINSTEIN

JOHN CHRISTMAN

J. DONALD MOON

MARC FLEURBAEY

DONALD GILLIES

DAVID M. LEVY

DAVID COLANDER

MARK KINGWELL

KEN KRESS

SHAUN P. HARGREAVES HEAP

PETER VALLENTYNE

BEN FINE

SALIM RASHID
Comment on Dawson's 'Exit, Voice and Values in Economic Institutions 101

Grounding Hypernormal: Toward a Contractarian Theory of Business Ethics

Review of Steven Bram and Alan Taylor's Fair division 113

Review of D. W. Haslett's Capitalism With Mortality 117

Review of Brian Barry's Justice as Impartiality 123

Review of H. Peyton Young's Equit: In Theory and Practice 128

Review of Charles R. McCann's Probability Foundations of Economic Theory 132

Review of Christopher J. Berry's The Idea of Luxury 134

Review of Thomas A. Boylan and Paschal F. O'Gorman's Beyond Rhetoric Methodology 140

Review of David Schmidtz's Rational Choice 142

Review of Jules L. Coleman's Risks and Wrongs 313

Review of John Coates's The Claims of Common Sense: Moore, Wittgenstein, Keynes and the Social Sciences 324

Review of L. W. Sumner's Welfare, Happiness, and Ethics $\mathbf{3 3 0}$

Review of G. A. Cohen's Self-Ownership, Freedom, and Equality 337

Review of T. M. Porter's Trust in Numbers 345 
KRISTIN

SHRADER-FRECHETTE

KEN BINMORE
Review of Peter Dorman's Markets and Mortality $\mathbf{3 4 8}$

Review of Brian Skyrms's Evolution of the Social Contract 352 


\section{Instructions to Authors}

Submitted articles and editorial correspondence should be sent to: The Editors, Economics and Philosophy, Dept of Philosophy, Lund University, Kungshuset, SE22222 Lund, Sweden. Books for review in Economics and Philosophy should be sent to Professor Christopher Morris, Department of Philosophy, Bowling Green State University, Bowling Green, Ohio 43403, USA. Correspondence may also be sent by e-mail to: econphil@fil.lu.se.

The journal publishes papers in English only. However, the editors are willing to consider initial submissions in French, and advise the authors whether to resubmit an English version. The final decision will be made on the basis of the English version only.

Please send four copies of submitted articles, in double-spaced type. Please send any covering letter in duplicate. Include an abstract of one hundred words or fewer. We are pleased to receive copies printed on both sides of the paper. The copies sent to referees will be anonymous, so the author's name and address should appear on a separate title page and not in the rest of the article. Please also remove other clues to your identity. Repeat the title of the article at the beginning of the text to be sent to referees. Submitted articles will not be returned to authors.

Authors of accepted articles will be asked to prepare a final version in the journal's style, following instructions that the editors will provide, and to submit it on disk together with a version on paper.

Submitting an article to Economics and Philosophy implies that it has not been published elsewhere and is not being considered for publication elsewhere. Authors must obtain written permission to reproduce any material for which they do not own the copyright. They will be asked to assign the copyright of their article, under certain conditions, to Cambridge University Press. Authors of articles will receive 25 offprints of their article free of charge; additional copies may be purchased if ordered at proof stage on the form provided. (In the case of joint contributions, offprints will be sent to the first named author unless otherwise requested.) 


\section{CAMBRIDGE}

\section{The Crisis of Vision in Modern Economic Thought}

\section{Robert Heilbroner} and William Milberg

A deep and widespread crisis affects modern economic theory. The authors' analysis attempts both to describe this state of affairs, and to suggest the direction in which economic thinking must move if it is to regain the relevance and remedial power it now pointedly lacks.

$\begin{array}{llll}\mathbf{E} 30.00 & \text { HB } & 0521497140 & 143 \mathrm{pp} . \\ \mathbf{E} 10.95 & \text { PB } & 0521497744 & \end{array}$

\section{Economic Analysis and Moral Philosophy}

\section{Daniel M. Hausman}

and Michael S. McPherson

This book discusses methods of economic evaluation in terms of welfare and other moral criteria, and examines how such techniques as social choice and game theory are relevant to philosophy.

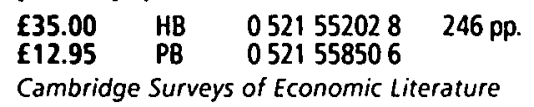

\section{Institutions in}

\section{Economics}

The Old and the New

Institutionalism

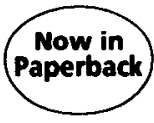

\section{Malcolm Rutherford}

This book examines and compares the two major traditions of institutionalist thinking in economics.

$$
\text { E14.95 PB } 0521574471 \quad 240 \text { pp. }
$$
Historical Perspectives on Modern Economics

\section{Egalitarian Perspectives}

Essays in Philosophical Economics

\section{John E. Roemer}

This book presents fifteen essays, written over the past dozen years, on egalitarianism. The essays explore contemporary philosophical debates on this subject, using the tools of modern economic theory, general equilibrium theory, game theory, and the theory of mechanism design.

£14.95 PB 0521574455368 pp.

\section{The Correspondence of} Alfred Marshall, Economist

\section{Edited by John K. Whitaker}

This three-volume work constitutes a comprehensive scholarly edition of the correspondence of the English economist, Alfred Marshall (18421924), one of the leading figures in the development of economics and the founder of the Cambridge School of Economics. The edition fills a longstanding gap in the history of economic thought with hitherto unpublished material.

Volume 1: Climbing, 1868-1890 f40.00 HB $0521558883432 \mathrm{pp}$. Volume 2: At the Summit, 1891-1902 John K. Whitaker E40.00 HB $0521558875550 \mathrm{pp}$.

Volume 3: Towards the Close, 1903-1924 f40.00 HB $0521558867550 \mathrm{pp}$.

Complete set

£115.00 HB $0521558891 \quad 416 \mathrm{pp}$.

Cambridge books are available from good bookshops, alternatively phone UK +44 (0)1223 325588 to order direct using your credit card, or fax UK +44(0)1223 325152 . 
All rights reserved. No part of this publication may be reproduced, in any form or by any means, electronic, photocopying or otherwise, without permission in writing from Cambridge University Press. Photocopying information for users in the U.S.A.: The Item-Fee Code for this publication (0266-2671/97 \$7.50 +10 ) indicates that copying for internal or personal use beyond that permitted by Sec. 107 or 108 of the U.S. Copyright Law is authorized for users duly registered with the Copyright Clearance Center (CCC) Transaction Reporting Service, provided that the appropriate remittance of $\$ 7.50$ per article is paid directly to: CCC 222 Rosewood Drive, Danvers, MA 01923. Specific written permission must be obtained from Cambridge University Press for all other copying. Contact the ISI Tearsheet Service, 3501 Market Street, Philadelphia, PA 19104, for single copies of separate articles.

\author{
(C) 1997 Cambridge University Press
}

CAMBRIDGE UNIVERSITY PRESS

The Edinburgh Building, Shaftesbury Road, Cambridge CB2 2RU, England 40 West 20 th Street, New York, NY 10011, U.S.A.

10 Stamford Road, Oakleigh, Melbourne 3166, Australia

Printed by Bell and Bain, Glasgow 


\title{
ECONOMICS AND PHILOSOPHY
}

\author{
Volume 13, Number 2
}

Essays

\section{David Dearmont and David A. Bessler}

Luc Van Liederkerke and Luc Lauwers

Stephen D. Parsons

\section{Charles Blackorby, Walter Bossert and David Donaldson}

Hamish Stewart

Amos Witztum

Philippe Fontaine

Vivienne Brown

Reviews

Ken Kress

Shaun P. Hargreaves Heap

Peter Vallentyne

Ben Fine

Salim Rashid

Kristin

Shrader-Frechette

Ken Binmore

CAMBRIDGE UNIVERSITY PRESS
A Beyesian Treatment of Duhem's Thesis: The Case of the 'Farm Problem' in Agricultural Economics 149

Sacrificing the Patrol: Utilitarianism, Future Generations and Infinity 159

Mises, the A Priori, and the Foundations of Economics: A Qualified Defence 175

Critical-Level Utilitarianism and the Population-Ethics Dilemma 197

The Law of Damages and the Prisoners' Dilemma: A Comment on 'Pure and Utilitarian Prisoners' Dilemmas 231

Distributive Considerations in Smith's Conception of Economic Justice 241

Identification and Economic Behavior Sympathy and Empathy in Historical Perspective 261

'Mere Inventions of the Imagination: A Survey of Recent Literature on Adam Smith 281

Review of Jules L. Coleman's Risks and Wrongs 313

Review of John Coates's The Claims of Common Sense: Moore, Wittgenstein, Keynes and the Social Sciences 324

Review of L. W. Sumner's Welfare, Happiness, and Ethics 330

Review of G. A. Cohen's Self-Ownership, Freedom, and Equality 337

Review of T. M. Porter's Trust in Numbers

Review of Peter Dorman's Markets and Mortality 348

Review of Brian Skyrms's Evolution of the Social Contract 352

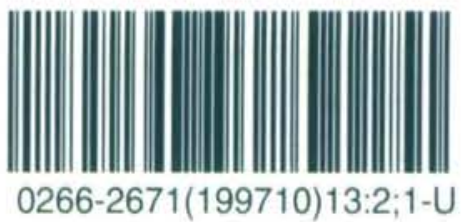

